\title{
Corporate Governance, Disclosure Quality, and Cost of Equity: Evidence from Pakistan
}

\section{Safia Nosheen ${ }^{*}$, Naveed-Ul-Haq ${ }^{* *}$ and Muhammad Faisal Sajjad $^{* * *}$}

\begin{abstract}
The link between disclosure of corporate information and the cost of equity in firms is one of the most important issues in finance. This paper aims to examine the connection between corporate governance, disclosure quality of information, and the cost of equity in Pakistani-listed (PSX-listed) firms. Using the Generalized Methods of Movements (Sys-GMM) model, a sample of 167 non-financial firms listed on Pakistan Stock Exchange (PSX) for the period of 2011-2015was analyzed. Sys-GMM estimation was applied to overcome the problem of endogeneity among corporate governance variables. To test the robustness of GMM estimations, we compared the results of pooled ordinary least squares (OLS) and fixed-effect estimations and found they did not overcome the problem of endogeneity, providing spurious results. We found a negative association between cost of equity and disclosure quality of financial statements. The findings suggested that the board size, concentrated ownership and CEO duality, are found as significant factors in reducing the cost of equity of PSX-listed firms. Audit committee independence and audit quality of the firm showed a positive relationship with the firm's cost of equity. Our findings suggest that employing a high-quality auditor and independent director's results in increased cost of equity for PSX-listed firms. Furthermore, no significant relationship between independence of the boards and duration of the authorizations of financial statements by the board of directors is found. The results also revealed the investors demand more return on their investments if inadequate and incomplete information is disclosed in the annual reports of the firms. This study provides useful insights for Pakistani corporate governance regulators, the executive management of Pakistani firms, and their investors.
\end{abstract}

Keywords: Corporate governance, disclosure quality, cost of capital, Pakistani listed firms

JEL Classifications: G30, G34,

\footnotetext{
* Assistant Professor, University of Management and Technology, Lahore, Pakistan.

** MS Finance Scholar, University of Management and Technology, Lahore, Pakistan.

*** Lecturer, University of Management and Technology, Lahore, Pakistan.
} 


\section{Introduction}

The history of corporate governance has several scandals e.g. Tyco, Enron and WorldCom. These scandals have shaken investors' trust in the equity markets in the world of corporate governance. To reinstate investors' trust and to protect shareholders, regulatory authorities and professional organizations in developed countries adopt a code of corporate governance. To ensure accountability, responsibility, and transparency within organizations, U.S.A in 2002 introduced the Sarbanes Oxley Act. Later these corporate governance codes are accepted by majority of the nations and firms find it more virtuous to practice good corporate governance standards to gain their investors' trust.

Finance theory argues that managers in organizations have the potential to improve the firms value by reducing investors' ambiguity about the performance of the firms in the upcoming future. However, this uncertainty is inherent in business and can never be reduced. The corporate managers can eliminate discrepancies in the information among market participants (Botosan, 2000). The theory suggests that corporate managers can reduce the information asymmetries in two ways. First, by increasing the disclosure of corporate information to market participants, and second, by making available some private corporate information to the public. When such private information are provided to investors a lesser rate of return is also acceptable on investments, and ultimately lower the cost of financing for firms.

Current study is targeting two aspects affecting the equity financing of firms: disclosure quality and corporate governance phenomenon. Information disclosure is the means through which a firm's administration provides information about past events and predicts opportunities for future growth to all investors (Al Attar, 2016). The information disclosure in financial statements and cost of financing of the firm is becoming a more crucial point for management and investors. The literature on disclosure policies affecting the equity financing of the firms is one of the thought provoking question in the field of finance and accounts (Beyer et al.,2010). The literature provides theoretical understanding and mechanisms behind the presence of an opposite relation between disclosure in financial statements and cost of financing of the firms (Gao,2010; Easley \& O'hara,2004). Studies by these researchers concluded that disclosures of accounting information is connected with reducing the cost of financing. Several researchers like (Hail, 2002; Kristandl \& Bontis, 2007; Orens, Aerts \& Cormier, 2010; and Richardson \& Welker, 2001) have explored this relationship which Botosan (1997) first proposed. 
There are multiple mechanisms behind the existence of the inverse relation between disclosure quality and financing of equity. In case more information is provided in the firm's financial statements, it enhances stock market liquidity and ultimately results in increased demand for the firm's stocks or reduces its transaction costs(Diamond \& Verrecchia,1991;Ajina, Sougne, \& Lakhal, 2015).Greater disclosure of information reduces the estimations-risk which may arise from investors' estimates of payoff distributions (Karkon \& Mazhari, 2013; Barry \& Brown, 1985; Clarkson, Guedes \& Thompson, 1996).

There have been varied results depicting disclosure and equity capital relationship. One study highlighted that the cost of capital declines with disclosure, arguing that disclosure quality had improved the investor's welfare that benefits in reducing the cost of financing (Gao, 2010). However, another study Botosan (1997) confirms the absence of relationship between disclosure quality and financing equity cost. Though varied outcomes are found when examining linkage between disclosure quality and equity financing cost, some researchers have moved one step further to identify the mechanisms behind the existence of the negative relationship between information given in financial statements and cost of equity of firms. Several studies have revealed that more information in financial statements enhances the liquidity of the stock, which ultimately brings high demand for the firm's stock and reduces transaction costs (Demsetz, 1968; Diamond \& Verrecchia, 1991; Glosten \& Milgrom, 1985). Other propose that greater information disclosure reduces the estimation of risks which may arise from the investors' estimations of payoff distributions (Barry \& Brown, 1985; Clarkson, Guedes \& Thompson, 1996).

The second main aspect of this study, a good corporate governance phenomenon, is helpful in reducing the equity financing cost of firms by decreasing the risk of expropriation by the majority stockholders. The agency theory is the starting point on the debate on corporate governance because it explains that firm management and shareholders have agency issues (Jensen \& Meckling, 1976). The agency cost arises when the management pursue for self-interest motives rather than shareholders' welfares. Therefore, it is imperative to set up an operative governance structure for the well-being of both the firm and shareholders. Robust corporate governance mechanism has an encouraging impact on the equity financing cost of the firm, however, these mechanisms generally are helpful for reducing the risk by firms and ultimately supportive for cost of equity of the firms (Donker, Poff \& Zahir, 2008). 
Studies conducted in developed countries with a high disclosure environment (e.g., U.S.A and Canada) found that cost of equity is reduced if more disclosure is provided (Richardson \& Welker 2001; Botosan, 1997). Recently, researchers diverted their interests towards finding this connection in developing and emerging economies, where an inferior level of disclosure of corporate information exists. These studies focused on Brazil, China, Malaysia, and Pakistan (Lopes \& de Alencar, 2010;Xiao-feng, Wei-ling, \& Ming-yi, 2006;Embong, Mohd-Saleh, \& Hassan 2012;Ali Shah \& Butt 2009). The findings of these studies open an avenue for researchers to study the linage among corporate governance, disclosure quality, and firms' equity financing in an atmosphere where an inferior quality of disclosure exist. These studies provide evidence for an opposite relationship among corporate governance, disclosure quality, and financing equity cost.

The aim of the research is to explore the association amongst disclosure quality, corporate governance mechanisms, and cost of financing using equity of Pakistani firms registered on Pakistan Stock Exchange (PSX) for the time of 2011-2015.

The following questions are addressed by this study:

- Does the disclosure quality reduce the cost of equity capital of Pakistani firms?

- Which governance attributes contribute to reducing the equity cost?

To manage and control the corporate governance of the companies operating in Pakistan, the Code of Corporate Governance was set by Securities and Exchange Commission of Pakistan (SECP) in 20021. These codes set the minimum benchmark for transparency about disclosure requirements, consistency in corporate practices, and governance standards. They provide rights to investors, particularly minority shareholders. SECP requires that all listed companies in Pakistan must follow these codes to operate their businesses in Pakistan. The code incorporates numerous proposals in accordance with a global standard of good practice. This code was an amendment of the Corporate Ordinance 1984, amended with the objective to fortify the rights of shareholders. The State Bank likewise ordered the utilization of the code for all recorded and non-recorded banks and Development Finance Institutes.

\footnotetext{
${ }^{1}$ Revised by SECP in April 2012
} 
There are several reasons we have focused our research on Pakistan. First, Pakistan's economy is developing, and, like other developing economies, Pakistani firms have concentrated ownership structure and family-owned firms dominating the market. In this environment, many of the shareholders not only hold ownership of the organization, but also become part of the management. Second, according to the Companies Ordinance 2017, there are no protections for shareholders who have less than $10 \%$ shareholding. This research investigates the linkages exists between the ownership structure and equity financing in a developing economy context. Third, corporate governance and performance have extensively researched in the economy. In contrast, the studies on financing cost and corporate governance mechanisms are limited (Ali Shah \& Butt, 2009 ; Butt \& Hasan, 2009). These studies used corporate governance variables such as CEO duality, composition of board, and board size, find mixed results. Similarly, an inverse relationship was examined between size of the board and managerial ownership with cost of equity of Pakistani firms (Ali Shah \& Butt, 2009). Further, a direct relationship was found between board independence and audit committee independence with equity financing. Finally, an AngloAmerican model of corporate governance has adopted by Pakistan to support the governance standards in the corporate sectors. The question of whether this model is appropriate for Pakistan has been raised, as this model was created in countries from which Pakistan has cultural differences.

The Current study contribute to the ever-growing corporate governance literature within a developing economy, by examining the linkages between disclosure quality and equity financing of Pakistani listed firms for the years 2011-2015. It provides a detailed investigation of the quality of disclosure in the financial statements adopted by the firms and its relationship with equity. Required return calculated by the traditional method, i.e. Capital Asset Pricing Model (CAPM) is used as a proxy for equity financing cost. The corporate governance attributes used in this research include board size, CEO duality, board independence, ownership concentration, audit committee independence, time line of authorization of annual reports by board of directors, and audit quality. This study uses Sys-GMM estimations to analyze the relationships and to test the robustness of the relationships to which we applied the comparative analysis of OLS and fixed-effect estimations. The statistical results of the current research suggest that disclosure quality, board size, CEO duality, and ownership concentration are helpful to reduce the cost of equity of Pakistani firms, while audit quality and independence of audit committee are directly linked with the equity financing cost. The findings of the study can be used by investors as a guide in the financial market to 
invest their finances with confidence in those firms that provide quality disclosure. The results of the study can effectively be utilized by the policy makers to make powerful governance policies so that the governance mechanism could be so effective for protecting the rights of the shareholders that investors could invest with full confidence.

\section{Literature Review and Hypothesis Development}

A usual argument in favor of corporate governance is that it affects the firm value and increases its future cash flow by limiting or eliminating the ability of managers and majority stockholders to excerpt private benefits. Corporate governance can influence firms' cost of equity via discount premiums applied to the firms' expected future cash flow. An increase in corporate governance and disclosure quality can decrease the information irregularity, leading to the reduction in uncertainty of future cash flow.

An operative Corporate governance structure is supposed to lessen the equity financing cost of firms in many ways. First, it controls and monitors the shareholders' and managers' actions, minimizing the risk of expropriation (Chen, Chen, \& Wei, 2009). Second, better corporate governance practices reduce the information asymmetry and lessen the ambiguity about future cash flow (Verrecchia, 2001; Clarkson et al., 1996). Lastly, the quality of disclosure information by firms may cause a decline in the monitoring costs of outsider investors, causing lower demand on rate on investments, possibly leading to an increase in firm value (Lombardo \& Pagano, 1999).

\subsection{Disclosure Quality and Cost of Equity}

Numerous studies (Richardson \& Welker, 2001; Hail, 2002; Gietzmann \& Ireland, 2005) have analyzed the connection between disclosure and equity financing cost. A study by Botosan (1997) has analyzed the connection between disclosure level and equity financing cost in American manufacturing firms. The findings showed an inverse relationship between information quality and equity financing cost.

Kothari, Li, \& Short (2009) by using content analysis have explored the disclosures outcome on cost of capital, forecast dispersion and return volatility. They analyzed more than 100,000 reports from analysts, news reporters, and disclosure reports from firm management. Their findings suggested that when a firm discloses favorable information it significantly reduces the firm's capital cost, forecast dispersion and its return volatility. 
Chen et al. (2003) conducted a study in Asia's emerging markets to find the association between corporate governance disclosure and equity financing cost. OLS regression estimates are used for analysis, they found a positive impact of disclosure and other corporate governance variables on equity financing cost. These findings suggest that a country's investor safety laws and a firm's corporate governance approaches are imperative tools for reducing the financing cost of the firms. Khlif, Samaha, \& Azzam(2015) investigated an emerging market, the Egyptian Stock Exchange, in a low disclosure atmosphere for the period of 2006-2009. The cost of equity was measured by CAPM. Multivariate analysis confirmed that disclosure plays a positive role for reducing the financing cost.

Poshakwale \& Courtis (2005) examined the disclosure and equity financing cost of the banking industry. A total of 135 banks from Europe Australia, and North America are used as sample in the study. Variables as beta, price earnings ratio, price to book ratio, and firms' size are the control variables. The findings of this study suggest that an improved level of disclosure linked with the decrease of equity financing cost. However, European banks showed greater cost reduction in a high disclosure environment.

Kristandl \& Bontis(2007) investigated the influence of voluntary disclosure on equity financing in Australia, Germany, Sweden, and Denmark for the year 2005, using 95 listed companies in these countries as sample. Using OLS regression, the results revealed that there is an inverse association between organizations' forward-oriented disclosure and equity financing, whereas a direct relationship exists between historical information and equity financing cost.

Michaels (2017) described a significant and inverse association between corporate social disclosure and firms' financing cost in a German setting. Dutta and Nezlobin (2016) have shown that disclosure is helpful to reduce the equity financing cost and for investor wellbeing. Their findings showed that a firm's financing cost is related with disclosure negatively for firms that have lower growth rate and vice versa. By reviewing the literature related to the disclosure quality and its association with financing cost, we want to re-examine the following hypothesis, in the context of the Pakistani market by using a robust methodology and an enhanced sample set:

H 1: Quality disclosure practices reduce the cost of equity capital for firms listed on PSX. 


\subsection{Corporate Governance Mechanisms and Cost of Equity}

Theoretically, corporate governance incorporates mechanisms that ensure shareholders and creditors a return on their investments (Shleifer et al. 1997). Corporate governance mechanisms solve the agency issues of shareholders and management and seek to secure the rights of the minority shareholders in most of the developing economies. Confident investors feel protected and they contribute in capital markets more energetically and are ready to give more for the firm's financing. This ultimately enhances the firm value and reduces the cost of financing of the firm.

To find the link between corporate governance and cost of financing by using equity, many studies use either a composite corporate governance index (Gul, Rashid, \& Muhammad,2016; Javid \& Iqbal, 2008; Javid \& Iqbal, 2010) while others use individual governance attributes such as board size, independence, independence of auditors, CEO duality and concentrated ownerships. For instance, Resmini (2016) studies Latin American companies to find the relationship between financing cost using equity and corporate governance. To measure the quality of corporate governance for Latin American companies' authors constructed the corporate governance index. The study spans from 2011-2013 and it includes 270 observations from 90 firms. The linear regression findings confirm that overall corporate governance is helpful in reducing the capital cost of the firms. By looking at individual components, they found that disclosure and board of directors are helpful factors for reducing the financing cost of firms while ownership structure and shareholders rights show no significant relationship with cost of equity.

Gul et al. (2016) explored the impact of corporate governance on cost of financing by using equity of small, medium and large Pakistani firms for the period of 2003-2014 using a sample of 200 firms. They used Weighted Average Cost of Capital (WACC) to measure the financing cost of Pakistani firms. Other variables used are corporate governance score, insider ownership, growth, debt ratio and firms' profitability. Using GMM estimations their findings suggest an inverse association between corporate governance of small, medium and large firms and cost of equity.

A study undertaken in Pakistan by Ali Shah \& Butt (2009), considering the impact of corporate governance on equity financing using 114 listed firms as sample for the period of 2003-2007. Using OLS and fixed effect estimation the empirical findings suggests an inverse relationship between board size and managerial ownership with equity financing and a 
direct connection between corporate governance, audit committee independence and board independence with equity cost of Pakistani firms.

In the existing literature on this question, most studies demonstrate an inverse association between corporate governance practice and firms' equity financing, but some studies also show that excessive regulatory control rises the firms cost of equity. Guedhami \& Mishra (2009) conducted a study on 9 Asian and 13 Western European countries using a total of 1335 firms and found significant results that excess control increases the firm's equity financing, and both are positively related to each other. These results provide the first piece of indication of the direct relationship between excess control and equity financing. Similarly; Hope et al. (2009) investigated the effect of excess auditors remuneration on firms equity financing in global markets. The authors argue that when a high remuneration is paid to the auditor, the investors may think that there is lack of independence in firms because the auditor is economically bounded to the client. An information risk increase that is related to the financial statements of the firms and ultimately it leads to an increased cost of equity of the firm.

Timely and accurate information are very important for making timely and accurate decision. The lags in information transmission increase the uncertainty among investors and they demand higher returns on their investments. The company's financing cost using equity increases if there is lag of timely information e.g.(Evans, 2015). Afify (2009) investigated the corporate governance and audit report lags by using 85 Egyptian-listed firms. Regression results show that CEO duality, audit committee independence and board independence are positively linked with the audit report lag while ownership concentration is statistically insignificant for audit report lag. Similarly, Botosan \& Plumlee(2002) reported that firms' equity financing decreases with increased level of disclosure in the financial statements but it increase when there is timely information disclosures. This is because stock volatility increases with timely disclosed information.

The corporate governance mechanisms and cost of equity literature has mix findings. The corporate governance mechanisms used here include CEO duality, board size, audit committee independence, board independence, ownership concentration, audit quality and timely authorization of annual reports by the board of directors. To evaluate the impact of governance mechanisms on the cost of equity financing in the Pakistani context, the following hypothesis are formulated: 
H 2: Board size is negatively associated with the cost of equity of the firms listed on PSX.

H 3: Board independence increases the cost of equity of the firms listed on PSX.

H 4: The independence of audit committee is positively related with the cost of equity of the firms listed on PSX.

H 5: CEO duality decreases the cost of equity of the firms listed on PSX.

H 6: Concentrated ownership reduces the cost of equity of the firms listed on PSX.

H 7: Timely disclosure of information has a positive relationship with the cost of equity of the firms listed on PSX.

H 8: Audit quality has a positive relationship with the cost of equity of the firms listed on PSX.

\section{Research Methodology}

\subsection{Population, Sample and Data}

The target population of this research study is companies listed on the PSX. Currently, there is a total of 580 companies listed on the PSX from 35 different sectors ${ }^{2}$ with a market capitalization of Rs.9595.241 billion. We randomly selected 167 non-financial firms spanning different sectors for the period of 2011 to 2015. This research uses secondary data for analysis that is taken from the sample companies' annual reports, Pakistan Stock Exchange and State Bank of Pakistan's web site. We have excluded financial companies from the analysis because they have special disclosure requirements and the cash flow requirement of financial companies for reinvestment analysis are dissimilar from non-financial firms. The regulatory requirement of financial firms are more burdensome especially after financial the crisis of 2009.Capital is used differently in the two types of companies: a manufacturing firm raises funds and issues equity to invest in assets, whereas financial companies use debt like a raw material that is further used into more useful financial products. Because of such differences financial companies are not included in the sample(see for example, Gietzmann \& Ireland, 2005; Orens et al., 2010; Ali Shah \& Butt, 2009).

\footnotetext{
${ }^{5}$ Revised by SECP in April 2012; on 35 sectors. The information is collected as of April 12 $2^{\text {th }}, 2017$ (www.ksestocks.com)
} 


\subsection{Methodology}

The current study is designed to test the influence of corporate governance (CG) and disclosure quality (DQ) on cost of equity (COE) of Pakistani firms, the dependent variable is COE and DQ and CG mechanisms are the independent variables. The following statistical techniques are used to test the hypothesis.

- Summary of Statistics

- Correlation matrix and variance inflation factors

- Ordinary Least Squares (OLS)

- Fixed effect estimations

- Generalized methods of moments (Sys-GMM)

Normality of the data is checked by analyzing the descriptive statistics. To test the multicollinearity among variables we apply a correlation matrix. The econometrics models used in this research are OLS, fixed effect and Sys-GMM estimations. The empirical studies based on OLS estimations could yield biased and unpredictable estimations because it entirely ignores the unobserved heterogeneity (e.g., Maddala, 1992). It is also expected that the econometric model faces bias because of the omitted variables. To address this problem we apply fixed effect estimations.

The issue is that our study uses the corporate governance variables and these variables are endogenous in nature as corporate governance variables are broadly inclined by its past performance. In that case dynamic endogeneity occurs (Wintoki, Linck, \& Netter, 2012).The fixed effect model also eliminates the problem of endogeneity to some extent but it is valid only in assumption that previous performance has no influence on current corporate governance performance (Wintoki, Link, \&Netter, 2012). Another estimation technique which overcomes the problem of endogeneity is Two-stage Least Squares estimates (2SLS). The 2SLS estimates apply instrument variables to solve the problem of endogeneity but proper exogenous instrument variables in the model must be identified and included. Identifying valid instrument variables in some cases can be difficult (see for example, Keane \& Runkle, 1992).

We use panel data model Generalized Methods of Moments, predominantly System GMM (Sys-GMM) estimations, closely following Wintoki (2007) to overcome the problem of serial correlation, heteroskedasticity, simultaneity bias and dynamic endogeneity. The GMM model was introduced in the series of papers(Holtz-Eakin et al. 1988; 
Arellano \& Bond 1991;Arellano \& Bover 1995 and Blundell \& Bond, 1998).There are two primary types of GMM estimations have two types: difference GMM and system GMM. In this research we use system GMM estimates, also called Blundell \& Bond (1998) estimator, because in the presence of high persistency among corporate governance variables, the difference GMM does not perform well. Sys-GMM estimator uses the lags of variables in level form to work as instrument variables in the model.

\subsection{Operational Model}

To find the impact of CG and DQ, we apply the following equation:

$$
\begin{aligned}
\text { COST }= & \alpha+\beta_{1} \text { SCORE }+\beta_{2} B S+\beta_{3} B I N D+\beta_{4} A U I N D+ \\
& \beta_{5} C D U+\beta_{6} O C+\beta_{7} \text { TLINE }+\beta_{8} A Q+\beta_{9} L S I Z E+ \\
& \beta_{10} N I+\beta_{11} L E V+\varepsilon \ldots \ldots \ldots \ldots \ldots \ldots \ldots
\end{aligned}
$$

Equation (1) is the operational model that we used in this study. We run this equation under three estimates i.e. OLS, fixed effect and Sys-GMM. COST is the dependent variable, which is the cost of equity of sample firms, measured using CAPM. The independent variables included in our model are disclosure quality score, independence of board of directors, the size of board, CEO duality, ownership concentration, the independence of audit committee, time line of authorization of financial statements and audit quality. We use firm size, profitability and leverage as control variable in the model. Similarly, $\alpha$ and $\beta$ are intercept and parameters of this model and $\varepsilon$ represents the error term.

\subsection{Variables}

\subsubsection{Estimating cost of equity}

COE or capital represents the least rate of return that shareholders demand in return for their investments in a company, and for a company it is the cost of capital (Botosan, 2006). Many researchers use different approaches to estimate COE of a firm such as the price earnings growth model, average realized returns as proxy for expected returns, weighted average cost of capital (in firms bearing debt financing), and capital asset pricing model (Boujelbene \& Affes, 2013;Hao, Zhang, \& Fang, 2014;Khan, 2016). According to Botosan(2006) these approaches to calculate the cost of capital are divided into two classes. The first class uses market risk, predetermined price, and risk-free rates for estimation of cost of equity as CAPM. The second class considers COE as internal rate of return which 
links the expectations of future cash flow to current stock (Gebhardt et al. 2001; Gode \& Mohanram 2003;Easton 2004).

These estimation methods use current stock prices to forecast the anticipated rate of return. Choice of these methods largely depends on data availability and its application (e.g., Gietzmann \& Ireland, 2005;Lee, Walker, \& Christensen, 2006). For this reason, we use CAPM to estimate COE of Pakistani firms. The approach was widely used in similar studies (Khlif et al., 2015;Hearn, 2010;Ali Shah \& Butt, 2009; Graham \& Harvey, 2001;Bozec \& Bozec, 2011). According to CAPM the cost of equity is:

$$
\operatorname{COST}_{i t}=R_{f t}+\left(R_{m t}-R_{f t}\right) \beta_{i}
$$

COST $=$ cost of equity

$R_{f t}=$ risk free rate

$R_{m t}=$ market rate of return

$\beta_{i}=$ market risk (non-diversifiable risk)

\subsubsection{Estimating the disclosure quality ${ }^{3}$}

Disclosure quality is measured by assigning a score to each piece of info delivered in the PSX-listed companies' annual reports. The listed firms of Pakistan follow the external reporting criteria published by the joint committees of the Institute of Chartered Accountants of Pakistan (ICAP) and the Institute of Cost and Management Accountants of Pakistan (ICMAP). These criteria specify items that must be included in the annual reports of a listed firm. We assign points to the company for disclosure of information in their annual reports. There are six broad categories for score distribution which are as follows:

- Corporate objectives

- Director's report/Chairman's report/CEO overview

- Disclosure

- Stakeholders information

- Shareholders information

\footnotetext{
${ }^{3}$ Our study follows the same criteria as used by Nosheen \& Chonglerttham (2013) for calculating disclosure quality scores. Details of this score distribution criteria can be provided by authors on request.
} 
- Corporate governance

The aggregate of each section score represents the disclosure quality of a company. The same criteria for measuring the disclosure quality is used by Nosheen\& Chonglerttham(2013) in the study for examining the impact of board leadership and audit quality on disclosure quality in Pakistani firms.

\subsubsection{Corporate governance mechanisms}

Literature provides the evidence that CG influences the firms COE (See for example Chalevas, 2011;Allegrini \& Greco, 2013;Jallow et al., 2012). This study combines different CG attributes to measure the impact of CG on the COE of firms listed on PSX. This includes size of company board, independence of the board, independence of audit committee, CEO role duality, ownership concentration, time line of authorization of annual reports time line and audit quality. Table 1 illustrates the details about the variables used in this research. 


\section{Table 1: Measurement of Variables}

\begin{tabular}{|c|c|c|}
\hline Variables & Abbreviations & Measurement \\
\hline Cost of equity & COST & $\begin{array}{l}\text { Cost of equity is the dependent variable; it is } \\
\text { measured by calculating Capital Asset Pricing } \\
\text { Model (CAPM) for sample firms. } \\
\text { COST }_{\text {it }}=R_{\mathrm{ft}}+\left(\mathrm{R}_{\mathrm{mt}}-\mathrm{R}_{\mathrm{ft}}\right) \beta_{\mathrm{i}}\end{array}$ \\
\hline $\begin{array}{l}\text { Disclosure } \\
\text { quality score }\end{array}$ & SCORE & $\begin{array}{l}\text { Disclosure quality score is independent variable. } \\
\text { The broad categories for SCORE distribution are } \\
\text { Corporate objectives, Directors report, Disclosure, } \\
\text { Stakeholders information, Shareholders } \\
\text { information and Corporate governance. The score } \\
\text { is allocated to these sections on the basis of } \\
\text { information disclosed by each section and the } \\
\text { aggregate SCORE is } 100 \text {. }\end{array}$ \\
\hline Board size & BS & $\begin{array}{l}\text { Board size represents the total members of board } \\
\text { in a company. }\end{array}$ \\
\hline $\begin{array}{l}\text { Board } \\
\text { independence }\end{array}$ & BIND & $\begin{array}{l}\text { Board independence is } \% \text { of non-executive } \\
\text { directors in total board size. }\end{array}$ \\
\hline $\begin{array}{l}\text { Audit } \\
\text { committee } \\
\text { independence }\end{array}$ & AUIND & $\begin{array}{l}\text { Audit committee independence is the \% of non- } \\
\text { executive directors in audit committee. }\end{array}$ \\
\hline CEO duality & CDU & $\begin{array}{l}\text { CEO duality is a dummy variable. If CEO holds a } \\
\text { position of the Chairman of the board also, we } \\
\text { assign } 0 \text {, otherwise } 1 .\end{array}$ \\
\hline Time line & TLINE & $\begin{array}{l}\text { Time line is the time period of the authorization of } \\
\text { financial statements by the board of directors. It is } \\
\text { a dummy variable. If financial statements are } \\
\text { authorized within } 45 \text { days of year ending we } \\
\text { assign } 1 \text {, otherwise } 0 \text {. }\end{array}$ \\
\hline $\begin{array}{l}\text { Ownership } \\
\text { concentration }\end{array}$ & OC & $\begin{array}{l}\text { Ownership concentration is the block holder } \\
\text { ownership of a company. The block holder of } 10 \% \\
\text { or more is taken into account for concentrated } \\
\text { ownership. }\end{array}$ \\
\hline Audit Quality & AQ & $\begin{array}{l}\text { Audit quality is measured by taking the ratio of } \\
\text { audit fee to net sales for the year. }\end{array}$ \\
\hline Leverage & LEV & $\begin{array}{l}\text { Leverage is calculated by dividing long term debt } \\
\text { with the total assets of a company. }\end{array}$ \\
\hline $\begin{array}{l}\text { Size of the } \\
\text { company }\end{array}$ & LSIZE & $\begin{array}{l}\text { Size is the total assets of the company. We take } \\
\text { natural log of total assets of analysis purpose. }\end{array}$ \\
\hline Net Income & NI & $\begin{array}{l}\text { Net income is the total net income of the company } \\
\text { after interest and tax. }\end{array}$ \\
\hline
\end{tabular}




\subsubsection{Other control variables}

Other than the corporate governance variables, past studies provide evidence that there are some other firm level characteristics which can influence on firms' corporate governance practices. We use three firm level variables leverage, firm size and profitability are taken as control variable that may influence the cost of equity of sample firms. The details and measurement of control variables is given in Table 1.

Agency theory argues that larger firms face greater agency problems because of their complexity in capital structures(e.g., Chow \& Wong, 1987; Bebchuk \& Weisbach, 2010). The resource dependence theory explores that larger firms usually reveal more info in their financial statements to secure required resources (Pfeffer \& Salancik, 1978). Studies confirm the positive and significant relationship between size of the firm and corporate governance compliance (Omar \& Simon, 2011; Allegrini \& Greco, 2013; Gupta \& Sharma, 2014).Zhu (2014) investigates the inverse relationship between firm's size and COE.

According to Jensen \& Meckling(1976) a firm that uses more external finance in its capital structure faces more agency problems because shareholders wants their money not to be involved in inefficient projects. Leverage offers tax savings but is also associated with the risk of default. Hence there was a direct relationship between firms' $\mathrm{COE}$ and leverage (Fama \& French, 1992; Gode \& Mohanram, 2003).

Both the signaling and agency theories argue that managers of the lucrative firms discloses more in order to sustain the position and remuneration (see for example, Haniffa \& Cooke, 2002). Legitimacy theory offers the same argument that executives of profitable firms reveal more information to maintain their continued presence. We expect firm's profitability is negatively related with the COC because higher profits increase returns on assets and ultimately reduce the default risk( $\mathrm{Zhu}, 2014)$.

\section{Results and Discussions}

\subsection{Summary of Statistics}

Summary statistics of the variables given in Table 2. COE has a mean value of 0.15 with a SD of 0.18 and a range of 1.1. The average disclosure quality score of sample firms is 68.46, with a large standard deviation of 23.08. The maximum and minimum score is 100 and 14 resulting in a range 
of 86 . The average board size is 8.26 , with a range and standard deviation of 11 and 1.68 respectively. According to Lipton \& Lorsch(1992) the ideal board size is 8 or 9 for efficient monitoring control. Our study reported the average board size falling within this range. Board independence and audit committee have a mean value of 0.55 and 0.71 respectively. This means the sample boards contained a greater number of outside directors, about $55 \%$ and $70 \%$ respectively. CEO duality and time line of authorization of annual reports by the board of directors are dummy variables and range from 0 to 1 . The average CEO duality and time line in the current sample is 0.85 and 0.26 respectively. The summary statistics on ownership concentration show that sample firms have an average concentration level of $50 \%$ and a range from 0 to $99 \%$. This means that most Pakistani firms are family controlled. The mean value of audit quality is 0.0037 . The average leverage of sample firms is 0.12 , which shows that most of the firms are relying on its internal rather than external financing. The average firm's size and net income of sample firms isRs. 22748 and Rs. 2383 respectively.

Table 2: Descriptive statistics

\begin{tabular}{lcccccc}
\hline Variables & N & Range & Minimum & Maximum & Mean & Std. Deviation \\
\hline COST & 825 & 1.100 & 0 & 1.100 & 0.150 & 0.184 \\
SCORE & 798 & 86 & 14 & 100 & 68.458 & 23.076 \\
BS & 795 & 11 & 4 & 15 & 8.260 & 1.678 \\
BIND & 795 & 0.933 & 0 & 0.933 & 0.551 & 0.235 \\
AUIND & 789 & 1 & 0 & 1 & 0.709 & 0.329 \\
CDU & 798 & 1 & 0 & 1 & 0.850 & 0.356 \\
OC & 799 & 99.050 & 0 & 99.050 & 50.453 & 27.632 \\
TLINE & 797 & 1 & 0 & 1 & 0.263 & 0.440 \\
AQ & 798 & 1.102 & -0.003 & 1.100 & 0.004 & 0.043 \\
LEV & 801 & 3.702 & 0.000 & 3.702 & 0.128 & 0.212 \\
SIZE (Rs. In & 801 & 553787 & 2 & 553790 & 22748 & 58118 \\
Million) & & & & & & \\
NI (Rs.in Million) & 800 & 133664 & -9749 & 123915 & 2383 & 10652 \\
\hline
\end{tabular}

\subsection{Correlation Matrix and Variance Inflation Factors}

Table 3 summarizes correlation results of all variables. Results demonstrate negative and significant relationships among COE and DQ score, board size ,CEO duality, and ownership concentration. DQ score is inversely associated with audit quality and directly related to all other variables. Similarly, board size shows positive and significant relationships with independence of board, independence of audit committee, CEO role duality, time line, size of the company, and leverage. Board independence shows positive and significant relationships with audit committee 
independence, time line, and net income. The independence of audit committee is positively related with time line and net income. The CEO role duality is negatively related with ownership concentration, audit quality, leverage, and net income and ownership concentration are positively associated with time line, leverage, and net income. time line is positively and significantly associated with control variables size of the company and net income, whereas audit quality is negatively related with size of the company.

The above results show the bivariate relationship of used in our analysis. We apply variance inflation factors (VIF) to test the multicollinearity among variables, we apply for the dependent variable COE. VIF results are presented in Table 4, which shows the absence of multicollinearity as VIF scores of independent variables are less than 10 (Hair et al., 1995, and Belsley, Kuh, \& Welsch, 2005).

Table 3: Correlation matrix

\begin{tabular}{lcccccccccccc}
\hline & COST & SCORE & BS & \multicolumn{1}{l}{ BIND AUIND } & CDU & OC & TLINE & AQ & LEV & LSIZE NI \\
\hline COST & 1 & - & - & - & - & - & - & - & - & - & - & - \\
SCORE & -.023 & 1 & - & - & - & - & - & - & - & - & - & - \\
BS & -.017 & $.329^{* *}$ & 1 & - & - & - & - & - & - & - & - & - \\
BIND & $.172^{* *}$ & $.137^{* *}$ & $.212^{* * *}$ & 1 & - & - & - & - & - & - & - & - \\
AUIND & $.221^{* * *}$ & $.218^{* * *}$ & $.167^{* *}$ & $.748^{* *}$ & 1 & - & - & - & - & - & - & - \\
CDU & $-.132^{* *}$ & $.271^{* *}$ & $.153^{* *}$ & -.009 & -.063 & 1 & - & - & - & - & - & - \\
OC & -.018 & $.126^{* *}$ & -.069 & -.068 & -.003 & $-.110^{* *}$ & 1 & - & - & - & - & - \\
TLINE & $.116^{* * *}$ & $.486^{* *}$ & $.268^{* *}$ & $.122^{* *}$ & $.125^{* *}$ & $.088^{*}$ & $.185^{* *}$ & 1 & - & - & - & - \\
AQ & $.161^{* *}$ & $-.071^{*}$ & -.026 & -.023 & -.010 & $-.078^{*}$ & .000 & .023 & 1 & - & - & - \\
LEV & .034 & .001 & .014 & -.042 & -.037 & -.014 & $.089^{*}$ & -.041 & -.016 & 1 & - & - \\
LSIZE & $.109^{* *}$ & $.415^{* *}$ & $.338^{* *}$ & .058 & .046 & .042 & .029 & $.338^{* *}$ & $-.173^{* *}$ & $.085^{*}$ & 1 & - \\
NI & $.188^{* * *}$ & $.136^{* *}$ & $.260^{* * *}$ & $.194^{* *}$ & $.108^{* *}$ & $-.115^{* *}$ & $.117^{* *}$ & $.182^{* *}$ & -.019 & $.150^{* *}$ & $.401^{* *}$ & 1 \\
\hline
\end{tabular}

Table 4: Variance inflation factors

\begin{tabular}{lccc}
\hline \multicolumn{3}{c}{ Dependent variable: COST } & \\
\hline & Independent variables & VIF & 1/VIF \\
\hline SCORE & 1.790 & 0.559 \\
BS & 1.300 & 0.767 \\
BIND & 2.410 & 0.414 \\
AUIND & 2.400 & 0.417 \\
CDU & 1.160 & 0.865 \\
TLINE & 1.47 & 0.681 \\
AQ & 1.050 & 0.950 \\
LSIZE & 1.620 & 0.618 \\
LEV & 1.040 & 0.958 \\
NI & 1.350 & 0.743 \\
\hline Mean VIF & \multicolumn{2}{c}{1.52} \\
\hline
\end{tabular}




\subsection{Results of OLS, Fixed Effect and Sys-GMM Estimations}

Table 5 reports the results of hypothesis testing using ordinary least squares, fixed-effect, and Sys-GMM. First we run equation (1) under OLS estimations. Column (1) of Table 5 show the results. Our first hypothesis states inverse relationship between COE and DQ of PSX-listed firms. The results shown in table1 confirm that COE is negatively related to DQ as $\mathrm{H}_{1}$ $(\beta=-0.0010, p<0.01)$. We accept $\mathrm{H} 1$.The board size is significantly and inversely related with $\mathrm{COE}$ as $\mathrm{H}_{2}(\beta=-0.1460, \mathrm{p}<0.01)$ hence $\mathrm{H} 2$ is accepted. Similarly, audit committee independence, audit quality, time line of authorization, firm size, and profitability show significant and positive relationships with COE of Pakistani firms. This leads us to accept $\mathrm{H} 4$ and $\mathrm{H} 7$ of this study. Equation (1) under OLS estimates does not control endogeneity as it faces the problem of omitted variables bias.

To address this problem we run equation (1) under fixed-effect estimates. The results are presented Table 5. Results reveal that under a fixed-effect model, only audit quality is significantly and directly associated with COE, whereas no other independent variables reach significance. The fixed-effects model results do not meet the objectives of this study, as a fixed-effects model assumes that corporate governance variables have no impact on its past and present performance (dynamic endogeneity), but in reality this does not happen in the case of such variables (Wintoki et al. 2012). To overcome the problem of dynamic endogeneity, we uses Sys-GMM which addresses the issue faced by OLS and fixed-effect models (Wintoki, 2007). Column (3) of Table 5 shows the result of the Sys-GMM estimations. They show that disclosure quality is significantly and negatively related with $\operatorname{COE}(\beta=-0.0003, p<0.05)$, leading to the acceptance of $\mathrm{H} 1$.

Board size significantly and negatively contributes towards the reduction in COE, and $(\beta=-0.0030, \mathrm{p}<0.01)$ supports the acceptance of $\mathrm{H} 2$. Board independence does not reach significance with cost of equity hence $\mathrm{H} 3$ is rejected. Audit committee independence is shown to have a value of $(\beta=0.0145, p<0.10)$, which indicates positive relationship with COE, hence we accept $\mathrm{H} 4$ of the study. $\mathrm{H} 5$ states that CEO duality is negatively related with COE of Pakistani firms. We found its value to be $(\beta=-0.0089, \mathrm{p}<0.10)$ which proves a significant and negative relationship with cost of equity. Thus H5 is accepted. We found ownership concentration to have a significant and inverse relationship with cost of equity of Pakistani firms, as its value $(\beta=-0.0002, \mathrm{p}<0.05)$ confirms. Hence, H6 of the study is accepted. 
H7 claims that timely disclosure of information in annual reports time line causes a reduction of firms' COE. Results show this relationship with cost of equity does not reach significance, so $\mathrm{H} 7$ is not accepted at the $1 \%, 5 \%$, or $10 \%$ confidence level. $\mathrm{H} 7$ is rejected. $\mathrm{H} 8$ states that audit quality has a positive relationship with COE of Pakistani firms. Its value $(\beta=$ $0.9572, \mathrm{p}<0.01$ ) supports our claim. H 8 is accepted.

Furthermore, control variables such as leverage and profitability do not have a significant impact on COE, whereas firm size is positively related to COE of PSX-listed firms.

Table 5: OLS, fixed effect and Sys-GMM estimation results

\begin{tabular}{lllllll}
\hline \multicolumn{7}{c}{ Dependent variable: COST } \\
\hline & 1) OLS estimations & $\begin{array}{c}\text { 2) Fixed } \\
\text { estimations }\end{array}$ & $\begin{array}{l}\text { 3) Sys-GMM } \\
\text { estimations }\end{array}$ \\
\hline $\begin{array}{l}\text { Independent } \\
\text { variables }\end{array}$ & Coeff & P-value & Coeff & P-value & Coeff & P-value \\
\hline Constant & -0.117 & 0.237 & 0.061 & 0.219 & -0.198 & $0.000^{* * *}$ \\
SCORE & -0.001 & $0.000^{* * *}$ & 0.000 & 0.612 & -0.000 & $0.040^{* *}$ \\
BS & -0.146 & $0.000^{* * *}$ & 0.001 & 0.351 & -0.003 & $0.013^{* * *}$ \\
BIND & -0.011 & 0.784 & 0.027 & 0.109 & -0.011 & 0.38 \\
AUIND & 0.139 & $0.000^{* * *}$ & -0.015 & 0.144 & 0.015 & $0.076^{*}$ \\
CDU & -0.017 & 0.338 & 0.004 & 0.502 & -0.009 & $0.085^{*}$ \\
OC & -0.003 & 0.108 & -9.670 & 0.954 & -0.000 & $0.041^{* *}$ \\
TLINE & 0.068 & $0.000^{* * *}$ & -0.004 & 0.786 & 0.006 & 0.292 \\
AQ & 0.695 & $0.000^{* * *}$ & 0.999 & $0.000^{* * *}$ & 0.957 & $0.000^{* * *}$ \\
LSIZE & 0.017 & $0.000^{* * *}$ & 0.002 & 0.307 & 0.012 & $0.000^{* * *}$ \\
LEV & 0.009 & 0.745 & 0.001 & 0.834 & 0.003 & 0.372 \\
NI & 2.312 & $0.000^{* * *}$ & -2.451 & 0.365 & -1.661 & 0.209 \\
Prob> F & 0.000 & & 0.000 & & 0.000 & \\
R-square & 0.161 & & 0.858 & & & \\
\hline
\end{tabular}

Note: ${ }^{* *}$ Significant at $1 \%$

**Significant at $5 \%$

* Significant at $10 \%$

\section{Summary and Conclusion}

The primary objective of this research was to investigate the relationship between CG mechanisms, DQ, and COE of PSX-listed nonfinancial companies for the period of 2011-2015. We introduced CAPM to estimate the $\mathrm{COE}$ of Pakistani firms. There are several methods to calculate the COE. Easton (2004) and Gebhardt et al. (2001) use other methods in their studies but CAPM is still commonly used for computing COE. The 
reason behind using CAPM in the context of Pakistani listed firms is the data availability.

The findings of this study reveal that DQ of financial statements is negatively related to the COE of Pakistani firms. This means a greater disclosure of information in financial statements causes a decrease in the firm's COE. Disclosure quality of Pakistani firms seems to be good as the average score of sample firms is 68.45 out of 100 . Our findings are in confirmation with other studies of the Pakistani context (Gul et al. 2016;Khan 2016;Ali Shah \& Butt 2009).

In this study efforts are made to find the effect of CG mechanisms on COE of PSX-listed firms. Our findings suggest that board size, CEO role duality, and concentration of ownership are significant and negatively linked with cost of equity. This means that larger boards, the combined role of CEO and Chairman, and concentrated ownership affect the cost of equity negatively. Most Pakistani listed firms are family-owned and have a large board size. In most of the firms, the role of CEO and Chairman is combined. These three indicators are considered a good sign for the reduction of cost of equity in PSX-listed firms. Further audit quality and independence of audit committee are positively related with COE firms. These findings recommend that employing a high-quality auditor and involvement of more independent directors in said committee ultimately increases the cost of equity of PSX-listed firms because of excess control. These findings are consistent with Butt \& Hasan (2009), Guedhami \& Mishra (2009), and Hope, et al. (2009). Moreover, board independence and time line of authorization of annual reports are not significant factors for cost of equity of Pakistani firms. The firms seeking to earn more profit and firms that are mainly reliant on external financing are also not significant for decreasing cost of equity. The firm's size has a positive relationship with cost of equity, as agency and resource dependence theory argues that larger firms face more agency problems. To solve this problem and to secure the required resources, firms are required to disclose more information in financial statements (Pfeffer \& Salancik, 1978; Bebchuk\& Weisbach, 2010).

The current research adds to the ever-growing literature to strengthen the agency theory in a developing economy, emphasizing the need for more disclosure and a strengthened governance structure for better economic and financial implications. Our study attempts to covers the limitations of previous research by using a robust methodology and an extensive measure of disclosure quality. The results highlight an important 
issue being that investors invest in firms with greater transparency and that make efforts towards keeping their investors informed of the firm's activity. It is imperative for standard-setters to understand why firms should transform their disclosure quality to protect the shareholders' rights.

The current study has following limitations. The first is sample size, which consists of only 167 non-financial firms of PSX for a period of 5 years. The results may not be applicable to all PSX-listed firms. Secondly, this study measures the cost of COE Pakistani firms using CAPM; it is important to mention here that many researchers argue that CAPM is a biased proxy for COE can bias the estimations (Botosan, 1997). However, the approach is still widely used due to the issue of data availability, and models based on forecasted earnings per share is difficult to use. Furthermore, the findings cannot be generalized to developed countries or emerging markets. Despite these limitations, this paper does provide important insights. Future research may be carried out on a bigger sample panel study on the determinants of COE and DQ of annual reports. Using other methodology for measuring cost of equity may also be a path for future research. 


\section{References}

Afify, H.A.E. (2009). Determinants of audit report lag: Does implementing corporate governance have any impact? Empirical evidence from Egypt. Journal of Applied Accounting Research, 10(1), 56-86.

Al Attar, M. K. (2016). Corporate Governance and Financial Statement Disclosure Quality in Jordanian Commercial Banks. International journal of Economics and Finance, 8(10),192-205.

Ali Shah, S. Z., \& Butt, S. A. (2009). The impact of corporate governance on the cost of equity: empirical evidence from pakistani listed companies. The Lahore Journal of Economics, 14(1) 139-171.

Allegrini, M,.\& Greco, G. (2013). Corporate boards, audit committees and voluntary disclosure: Evidence from Italian listed companies. Journal of Management E Governance, 17(1), 187-216.

Ajina, A., Sougne, D., Lakhal,F. (2015).Corporate disclosure, Information Asymmetry and Stock Market Liquidity In France. The Journal of Applied Business Research 31(4),1223-1238

Arellano, M.,\& Bond, S. (1991). Some tests of specification for panel data: monte carlo evidence and an application to employment equations. The Review Of Economic Studies, 58(2), 277-297.

Arellano, M., \& Bover, O. (1995). Another look at the instrumental variable estimation of error-components models. Journal of Econometrics, 68(1), 29-51.

Barry, C. B, \& Brown, S. J. (1985). Differential information and security market equilibrium. Journal of Financial and Quantitative Analysis, 20(4), 407-422.

Bebchuk, L. A, \& Weisbach, M. S. (2010). The State Of Corporate Governance Research. Review of Financial Studies, 23(3), 939-961.

Belsley, D. A., Kuh, E., \& Welsch, R. E. (2004). Regression diagnostics: Identifying influential data and sources of collinearity. New York: Wiley.

Beyer, A., Cohen, D. A., Lys, T.Z., \& Walther, B. R. (2010). The financial reporting environment: Review of the recent literature. Journal of Accounting And Economics, 50(2), 296-343. 
Blundell, R., \& Bond, S. (1998). Initial conditions and moment restrictions in dynamic panel data models. Journal of Econometrics, 87(1), 115-143.

Botosan, C. A. (1997). Disclosure level and the cost of equity capital. The Accounting Review, 72(3), 323-349.

Botosan, C. A. (2000). Evidence that greater disclosure lowers the cost of equity capital. Journal of Applied Corporate Finance, 12(4), 60-69.

Botosan, C. A. (2006). Disclosure and the cost of capital: what do we know? Accounting and Business Research, 36(sup 1), 31-40.

Botosan, C. A.,\& Plumlee, M. A. (2002). A re-examination of disclosure level and the expected cost of equity capital. Journal of Accounting Research, 40(1), 21-40.

Boujelbene, M. A., \& Affes, H. (2013). The impact of intellectual capital disclosure on cost of equity capital: A case of French firms. Journal of Economics Finance and Administrative Science, 18(34), 45-53.

Bozec, Y., \& Bozec, R. (2011). Corporate governance quality and the cost of capital. International Journal of Corporate Governance, 2(3/4), 217-236.

Butt, S. A., \& Hasan, A. (2009). Impact of ownership structure and corporate governance on capital structure of Pakistani listed companies.International Journal of Business and Management, 4(2), 50-57.

Chalevas, C., G. (2011). The effect of the mandatory adoption of corporate governance mechanisms on executive compensation. The International Journal of Accounting, 46(2), 138-174.

Chen, K. C.W., Chen, Z., \& Wei, K.C. J., (2009). Legal protection of investors, corporate governance, and the cost of equity capital. Journal of Corporate Finance, 15(3), 273-289.

Chen, K. C.W., Chiang.W.K., \&Chen, Z. (2003). Disclosure, corporate governance, and the cost of equity capital: evidence from Asia's emerging markets. Available at SSRN: https:/ /ssrn.com/abstract $=422000$ 
Chow, C. W., \& Wong, B. Adrian. (1987). Voluntary financial disclosure by Mexican corporations. Accounting Review, 533-541.

Clarkson, P., Guedes, J., \& Thompson, R. (1996). On the diversification, observability, and measurement of estimation risk. Journal of Financial and Quantitative Analysis, 31(1), 69-84.

Demsetz, H. (1968). The cost of transacting. The Quarterly Journal Of Economics, 82(1), 33-53.

Diamond, D. W., \& Verrecchia, R. E. (1991). Disclosure, liquidity, and the cost of capital. The Journal Of Finance, 46(4), 1325-1359.

Donker, H., Poff, D., \& Zahir, S. (2008). Corporate values, codes of ethics, and firm performance: A look at the Canadian context. Journal of Business Ethics, 82(3), 527-537.

Dutta, S., \& Nezlobin, A. (2017). Information Disclosure, Firm Growth, and the Cost of Capital. Journal of Financial Economics, 123(2), 415-431.

Easley, D., \& O'hara, M. (2004). Information and the cost of capital. The journal of finance, 59(4), 1553-1583.

Easton, P. D. (2004). PE ratios, PEG ratios, and estimating the implied expected rate of return on equity capital. The Accounting Review, 79(1), 73-95.

Embong, Z., Mohd-Saleh, N., \& Hassan, M.S. (2012). Firm size, disclosure and cost of equity capital. Asian Review of Accounting, 20(2), 119-139.

Evans, M. E. (2015). Commitment and cost of equity capital: An examination of timely balance sheet disclosure in earnings announcements. Contemporary Accounting Research, 33(3), 1136-1171

Fama, E. F., \& French, K. R. (1992). The cross-section of expected stock returns. Journal of Finance, 47(2), 427-465.

Gao, P. (2010). Disclosure quality, cost of capital, and investor welfare. The Accounting Review, 85(1), 1-29. 
Gebhardt, W. R., Lee, C.M.C.,\& Swaminathan, B. (2001). Toward an implied cost of capital. Journal Of Accounting Research, 39(1), 135176.

Gietzmann, M.B., \& Ireland, J.C. (2005). Discussion of Cost of capital, strategic disclosures and accounting choice. Journal of Business Finance E Accounting, 32(3-4), 599-634.

Glosten,L.R., \& Milgrom, P. R., (1985). Bid, ask and transaction prices in a specialist market with heterogeneously informed traders. Journal of Financial Economics, 14(1), 71-100.

Gode, D., \& Mohanram, P. (2003). Inferring the cost of capital using the Ohlson-Juettner model. Review Of Accounting Studies, 8(4), 399-431.

Graham, J. R., \& Harvey, C. R. (2001). The theory and practice of corporate finance: Evidence from the field. Journal Of Financial Economics, 60(2), 187-243.

Guedhami, O., \& Mishra, D. (2009). Excess control, corporate governance, and implied cost of equity: international evidence. Financial Review, 44, 489-524

Gul, S., Rashid, A., \& Muhammad, F. (2016). The impact of corporate governance on cost of capital: The case of small, medium and large cap firms. Journal Of Business Studies, 12(1).

Gupta, P., \& Sharma, A. M. (2014). A study of the impact of corporate governance practices on firm performance in Indian and South Korean companies. Procedia-Social and Behavioral Sciences, 133, 4-11.

Hail, L. (2002). The impact of voluntary corporate disclosures on the exante cost of capital for Swiss firms. European Accounting Review, 11(4), 741-773.

Hail, L., \& Leuz, C. (2006). International differences in the cost of equity capital: Do legal institutions and securities regulation matter? Journal Of Accounting Research, 44(3), 485-531.

Hair, J., Joseph, F., Anderson, R. E., Tatham, R. L., \& William, C. (1995). Multivariate data analysis with readings. New Jersy: Prentice Hall. 
Haniffa, R. M., \& Cooke,T. E. (2002). Culture, corporate governance and disclosure in Malaysian corporations. Abacus, 38(3), 317-349.

Hao, L., Zhang, J.H., \& Fang, J. (2014). Does voluntary adoption of XBRL reduce cost of equity capital? International Journal of Accounting and Information Management, 22(2), 86-102.

Hearn, B. A.(2010). Costs of Equity in North Africa's equity markets: an Industrial Sector Study. Last retrievedhttps://papers.ssrn.com/sol3/papers.cfm?abstract_id=1535427

Holtz-Eakin, D., Newey, W., \& Rosen, H. S. (1988). Estimating vector autoregressions with panel data. Econometrica: Journal of the Econometric Society, 1371-1395.

Hope, O. K., Kang, T., Thomas, W. B., \& Yoo, Y. K. (2009). Impact of excess auditor remuneration on the cost of equity capital around the world. Journal of Accounting, Auditing E Finance, 24(2), 177-210.

Javid, A. Y., \& Iqbal, R. (2010). Corporate governance in Pakistan: Corporate valuation, ownership and financing. Working Papers \& Research Reports, 2010.

Javid, A. Y., \& Iqbal, R. (2008). Does corporate governance effects firm performance in case of Pakistani market. MPRA Working Paper No. 37567

Jensen, M. C., \& Meckling, W. H. (1976). Theory of the firm: Managerial behavior, agency costs and ownership structure. Journal of Financial Economics, 3(4), 305-360.

Karkon, A., Mazhari, R. (2013). Investigating the Relationship between Disclosure Quality in Information Systems and Securities Liquidity in Tehran Stock Exchange. International Research Journal of Management Sciences. 1 (4), 88-92.

Keane, M. P., \& Runkle, D. E. (1992). On the estimation of panel-data models with serial correlation when instruments are not strictly exogenous. Journal of Business \& Economic Statistics, 10(1), 1-9.

Khan, M. Y., (2016). Corporate governance and cost of capital: evidence from Pakistani listed firms. PhD Thesis, University of Glasgow. 
Khlif, H., Samaha, Khaled., \& Azzam, I. (2015). Disclosure, ownership structure, earnings announcement lag and cost of equity capital in emerging markets: The case of the Egyptian stock exchange. Journal of Applied Accounting Research, 16(1), 28-57.

Kothari, S.P., Li, Xu., \& Short, J. E. (2009). The effect of disclosures by management, analysts, and business press on cost of capital, return volatility, and analyst forecasts: A study using content analysis. The Accounting Review, 84(5), 1639-1670.

Kristandl, G., \& Bontis, N. (2007). The impact of voluntary disclosure on cost of equity capital estimates in a temporal setting. Journal of Intellectual Capital, 8(4), 577-594.

Lee, E., Walker, M., \& Christensen, H. B. (2006). The cost of capital in Europe: An empirical analysis and the preliminary impact of international accounting harmonisation: Certified Accountants Educational Trust.

Lipton, M., \& Lorsch, J. W., (1992). A modest proposal for improved corporate governance. The Business Lawyer, 48(1), 59-77.

Lombardo, D., \& Pagano, M., (1999). Law and equity markets: A simple model. CSEF Working Papers25, Centre for Studies in Economics and Finance (CSEF), University of Naples, Italy.

Lopes, A. B., \& de Alencar, R. C. (2010). Disclosure and cost of equity capital in emerging markets: The Brazilian case. The International Journal of Accounting, 45(4), 443-464.

Maddala, G. S.(1992). Introduction to econometrics. New York, Macmillan.

Michaels. A. (2017). Relationship of corporate social responsibility disclosure on information asymmetry and the cost of capital. Journal of Management Control, 28(3), 251-274

Nosheen, S.\& Chonglerttham, S. (2013). Impact of board leadership and audit quality on disclosure quality: Evidence from Pakistan. International Journal of Disclosure and Governance, 10(4), 311-327.

Omar, B., \& Simon, J. (2011). Corporate aggregate disclosure practices in Jordan. Advances in Accounting, 27(1), 166-186. 
Orens, R., Aerts, W., \& Cormier, D. (2010). Web-based non-financial disclosure and cost of finance. Journal of Business Finance $\mathcal{E}$ Accounting, 37(9-10), 1057-1093.

Pfeffer, J., \& Salancik, G. R. (1978). The external control of organisations. New York.

Poshakwale, S., \& Courtis, J. K. (2005). Disclosure level and cost of equity capital: evidence from the banking industry. Managerial and Decision Economics, 26(7), 431-444.

Resmini, F. (2016). Corporate governance and cost of equity: empirical evidence from Latin American companies. Corporate Governance: The International Journal of Business in Society, 16(5), 831-848.

Richardson, A. J., \& Welker, M. (2001). Social disclosure, financial disclosure and the cost of equity capital. Accounting, Organizations and Society, 26(7), 597-616.

Shleifer, A,.Vinshny, R. W.(1997) A Survey of Corporation Govenance. Journal of Finance, 52(2), 737-783.

Verrecchia, R. E. (2001). Essays on disclosure. Journal of Accounting and Economics, 32(1), 97-180.

Wintoki, M. B. (2007). Corporate boards and regulation: The effect of the Sarbanes-Oxley Act and the exchange listing requirements on firm value. Journal of Corporate Finance, 13(2), 229-250.

Wintoki, M. B., Linck, J. S., \& Netter, J. M. (2012). Endogeneity and the dynamics of internal corporate governance. Journal of Financial Economics, 105(3), 581-606.

Xiao-feng, H., Wei-ling, L., \& Ming-yi, Li. (2006). Empirical study of the relationship between voluntary disclosure and the cost of equity capital. Paper presented at the International Conference on Management Science and Engineering, 2006.

Zhu, F. (2014). Cost of capital and corporate governance: International study. International Review of Finance, 14(3), 393-429. 